\title{
Authorship and its abuse in a scientific publication.
}

\author{
Md. Ashif |qbal ${ }^{1 *}$
}

\section{AFFILIATION:}

1. Md. Ashif Iqbal*

Associate Professor \& Head

Dept. of Periodontology \& Oral Pathology

Update Dental College, Bangladesh

Chief Editor, Update Dental College Journal

Mail: drasif100@gmail.com

\section{Article info.}

Received: 17 January 2021

Accepted: 23 February 2021

Volume: Vol-11, Issue-1, April 2021

DOI: https://doi.org/10.3329/updcj.v11i1.52999

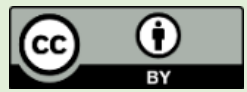

(C) Authors retain copyright and grant the journal right of first publication with the work simultaneously licensed under Creative Commons Attribution License CC - BY 4.0 that allows others to share the work with an acknowledgment of the work's authorship and initial publication in this journal.

https://creativecommons.org/licenses/by/4.0/

Publisher: Update Dental College, Dhaka, Bangladesh

Web: www.updatedentalcollege.edu.bd

E-mail: updcj@hotmail.com

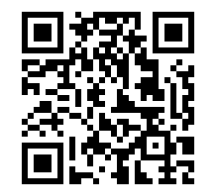

Scan QR code to see the latest issue

* Corresponding Author

Md. Ashif Iqbal*

Associate Professor \& Head

Dept. of Periodontology \& Oral Pathology

Update Dental College, Bangladesh

Mail: drasif100@gmail.com

https://orcid.org/0000-0002-9490-7927

Cell: +8801716116080

\section{INTRODUCTION}

Authorship of a research in scholarly publishing is asserted by those who contributed intellectually to the completion of the research described in the work. Even writing the whole paper, according to other criteria, would not constitute authorship unless the writer was already engaged in at least one other stage of the research. There are many forms of authorship, and there is exploitation authorship in the scientific community. Concern with these terms and the use of standard publishing principles ethically honors one's research work.

\section{THE ICMJE RECOMMENDS THAT AUTHORSHIP BE BASED ON THE FOLLOWING 4 CRITERIAS: (1)}

$>$ Substantial contributions to the conception or design of the work; or the acquisition, analysis, or interpretation of data for the work; AND

$>$ Drafting the work or revising it critically for important intellectual content; AND

$>$ Final approval of the version to be published; AND

> Agreement to be accountable for all aspects of the work in ensuring that questions related to the accuracy or integrity of any part of the work are appropriately investigated and resolved.

\section{DIFFERENT TYPES OF AUTHORSHIP:}

There are commonly three types of author like: First Author Co-author and Corresponding author.

First author:

First author is the one who carries out the bulk of the experiments.

(2) , First author has an important contribution to -

$>$ Experimental design,

$>$ Data analysis,

$>$ Data interpretation and

$>$ Writing of the manuscript.

The corresponding author conventionally, also called 'last author'.is in most cases the supervisor or the principal investigator.

He has major contribution in -

$>$ The design of the work,

$>$ He will supervise experiments,

> He will verify or even contribute to data analysis, data interpretation and writing of the manuscript.

$>$ Primary responsibility for communication with the journal during the manuscript submission, peer review, and publication process

$>$ Ensures that all the journal's administrative requirements, such as providing details of authorship, ethics committee approval, clinical trial registration documentation, and gathering conflict of interest forms and statements, are properly completed

$>$ Should be available throughout the submission and peer review process to respond to editorial queries in a timely way.

If you are a named co-author, this means that you: (3)

$>$ Made a significant contribution to the work reported, whether that's in the conception, study design, execution, acquisition of data, analysis and interpretation, or in all these areas.

$>$ Have drafted or written, or substantially revised or critically reviewed the article.

$>$ Have agreed on the journal to which the article will be submitted. 
$>$ Reviewed and agreed on all versions of the article before submission, during revision, the final version accepted for publication, and any significant changes introduced at the proofing stage.

$>$ Agree to take responsibility and be accountable for the contents of the article and to share responsibility to resolve any questions raised about the accuracy or integrity of the published work.

\section{ORDER AUTHOR NAMES:}

Based on relative contribution:

1. First author first

2. Co-authors according to contribution

3. Traditionally, corresponding author at last.

There could be multiple first authors, or corresponding authors these additional first authors equally contributed can be noted by an asterisk other symbol accompanied by an explanatory note.

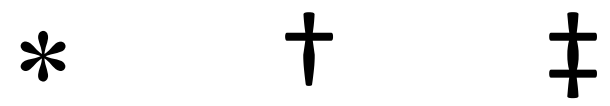

This practice arose as some journals wanted to increase accountability by requiring senior lab members to review all data and interpretations produced in their labs. Here is an example of multiple first authorship contribution. (https://doi.org/10.3329/updci.v11i1.53005)

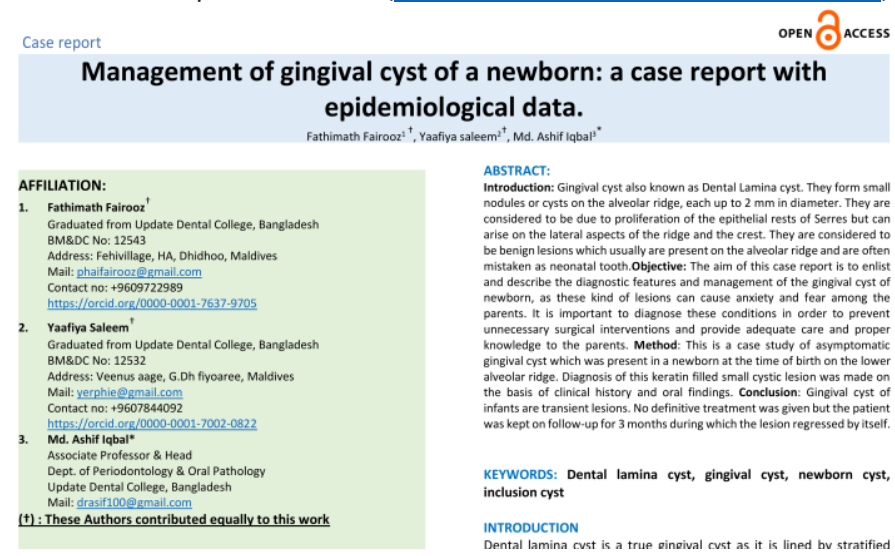

\section{ACKNOWLEDGEMENT:}

Contributors who meet fewer than criterias (IAccording to the ICMJE recommends) for authorship should not be listed as authors, but they should be acknowledged. Examples of activities that alone (without other contributions) do not qualify a contributor for authorship are acquisition of funding; general supervision of a research group or general administrative support; and writing assistance, technical editing, language editing, and proofreading. Those whose contributions do not justify authorship may be acknowledged individually or together as a group under a single heading (e.g. "Clinical Investigators" or "Participating Investigators"), and their contributions should be specified (e.g., "served as scientific advisors," "critically reviewed the study proposal," "collected data," "provided and cared for study patients", "participated in writing or technical editing of the manuscript").

Because acknowledgment may imply endorsement by acknowledged individuals of a study's data and conclusions, editors are advised to require that the corresponding author obtain written permission to be acknowledged from all acknowledged individuals. (4)

2 | P a g e

AUTHORSHIP ABUSE:

When a person is listed as an author, who has not provided any significant assistance to the study is defnitely an authorship abuse.

Different types of abuse are happening with or without concentration in scientific publication.

Kavin strage from Vanderbilt University Medical Center, Nashville, Tennessee, has been describe in details different types of authroship abuse and recommendation to minimize these abuse has been mention here: (5)

Type of
Authorship
Abuse

\section{Coercion} authorship

\begin{tabular}{|l} 
\\
\hline Honorary, guest, \\
or gift authorship
\end{tabular}
or gift authorship

Mutual support authorship

Ghost authorship

Denial of authorship

Duplication authorship
Use of intimidation tactics to gain authorship. Arguably a serious form of scientific misconduct

Authorship awarded out of respect or friendship, in an attempt to curry favor and/or to give a paper a greater sense of legitimacy.

Agreement by two or more investigators to place their names on each other's papers to give the appearance of higher productivity.

Publication of the same work in multiple journals.

Papers written by individuals who are not included as authors or acknowledged.

Publication of work carried out by others without providing them credit for their work with authorship or formal acknowledgment. A form of plagiarism and therefore scientific misconduct. 
AUTHORSHIP DISPUTES (5)

1. All research institutions, journals, and scientific societies should have in place formal authorship policies. The threshold for authorship on a scientific paper should be a direct and significant intellectual contribution to the study. All authors should have contributed to the writing of the manuscript. At a minimum, each author should have written at least the portion of the manuscript in which his/her contribution is discussed and should be able to take public responsibility for that contribution

2. All research institutions should have in place a well-recognized mechanism for addressing authorship disputes that cannot be resolved by the authors themselves. Authorship dispute resolution committees should comprise both senior and junior investigators and should be free from all real and perceived conflicts of interest.

3. Research institutions should never be allowed to be decision making bodies in authorship disputes. The role of the institution is to provide a fresh set of eyes on the problem and to assist the individuals involved in the dispute to arrive at an ethical and professional solution.

4. Authorship dispute resolution committees should have the authority to recommend that disciplinary action be pursued if clear evidence of abusive authorship practices is uncovered. At a minimum, individuals who abuse authorship should be required to satisfactorily complete a bioethics course. "Coercion authorship " and "denial of authorship" (see Table 1) should be treated as scientific misconduct and be referred to appropriate institutional bodies for further investigation and disciplinary action.

5. All letters of submission accompanying manuscripts should include an authorship verification statement that is signed by each coauthor and that describes his/her specific contributions.

6. The specific roles of all coauthors should be included in the published article. Deliberate falsification of the description of coauthor contributions should be viewed as scientific misconduct.

7. Every effort should be made to avoid authorship problems from the outset. Authorships should be negotiated and defined in writing at the beginning of an investigation. Frequent communication between all coauthors should occur while investigations are ongoing. Authorship should be discussed regularly and redefined in writing if necessary

\section{CONCLUSION}

Setting authorship criteria, as the ICMJE has done, is evidently inadequate for journal editors. Ignoring the misuse of authorship tarnishes the whole procedure. Simply asking both parties to sign a written declaration of authorship engagement to formally back up a related statement of commitment that is contained in the report as a footnote could go a long way toward curbing this practice and maintaining the jurisdiction over scientific authorship.

However, there is no guarantee that signing the form and making the statement won't simply become part of the bargaining process, allowing the abuse to continue. Social awareness development within researcher community in a broader way could mimic the condition.

3 I P a g e
1. ICMJE | Recommendations | Defining the Role of Authors and Contributors, http://www.icmje.org/recommendations/browse/roles-andresponsibilities/defining-the-role-of-authors-and-contributors.html

2. Bhattacharya S. Authorship issue explained. Indian Journal of Plastic Surgery. 2010 Jul 1;43(2):233-4. https://doi.org/10.4103/0970-0358.73482 PMid:21217997 PMCid:PMC3010799

3. Defining authorship | Writing Your Paper | Taylor \& Francis, https://authorservices.taylorandfrancis.com/editorialpolicies/defining-authorship-research

4. Submissions | Update Dental College Journal, https://www.banglajol.info/index.php/UpDCJ/about/submissions

5. Strange K. Authorship: why not just toss a coin? American Journal of Physiology-Cell Physiology. 2008 Sep;295(3):C567-75. https://doi.org/10.1152/ajpcell.00208.2008 PMid:18776156 PMCid:PMC2544445

\section{To submit your manuscript, Mail us to : updcj@hotmail.com \\ To see our latest issue, click the following link https://www.banglajol.info/index.php/UpDCJ}

